This report was prepared as an account of work sponsored by the United States Government. Neither the United States nor the U.S. DOE, nor any of their employees, nor any of their contractors, subcontractors, or their employees, makes any warranty expressed or implied, or assumes any legal liability or responsibility for the accuracy, completeness or usefulness of any information, apparatus, product or process disclosed, or represents that its use would not infringe privately-owned rights.

Printed in the United States of America

Available from

National Technical Information Service

U.S. Department of Commerce

5285 Port Royal Road

Springfield, Virginia 22161

Price: Printed Copy $\$ 5.25$; Microfiche

7.00

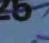




\section{DISCLAIMER}

This report was prepared as an account of work sponsored by an agency of the United States Government. Neither the United States Government nor any agency Thereof, nor any of their employees, makes any warranty, express or implied, or assumes any legal liability or responsibility for the accuracy, completeness, or usefulness of any information, apparatus, product, or process disclosed, or represents that its use would not infringe privately owned rights. Reference herein to any specific commercial product, process, or service by trade name, trademark, manufacturer, or otherwise does not necessarily constitute or imply its endorsement, recommendation, or favoring by the United States Government or any agency thereof. The views and opinions of authors expressed herein do not necessarily state or reflect those of the United States Government or any agency thereof. 


\section{DISCLAIMER}

Portions of this document may be illegible in electronic image products. Images are produced from the best available original document. 


\title{
SPENT FUEL INTEGRITY DURING TRANSPORTATION
}

\section{Hanford Engineering Development Laboratory}

\author{
C.W Funk \\ L.D. Jacobson
}

January 1980

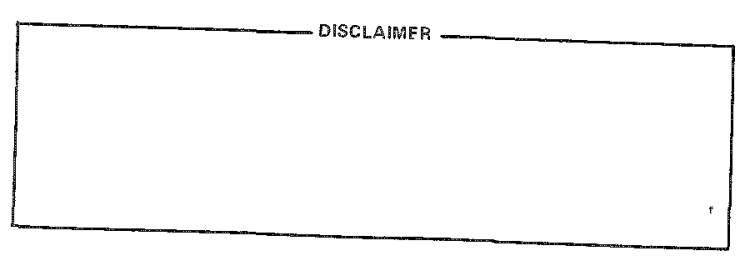

HAMFORD ENGINEERING DEVELOPMENT LABORATORY

Operated by Westinghouse Hanford Company

P.0. Box 1970 Richland, WA 99352

A Subsidiary of Westinghouse Electric Corporation

Prepared for the U.S. Department of Energy under Contract No. DE-AC14.76FF02170 
HEDL-TME 78-58

UC-85

SPENT FUEL INTEGRITY DURING TRANSPORTATION

C. W. Funk

L. D. Jacobson

\begin{abstract}
$\underline{\text { ABSTRACT }}$
The conditions of recent shipments of light water reactor spent fuel were surveyed. The radioactivity level of cask coolant was examined in an attempt to find the effects of transportation on IWR fuel assemblies. Discussion included potential cladding integrity loss mechanisms, canning requirements, changes of radioactivity levels, and comparison of transportation in wet or dry media. Although integrity loss or degradation has not been identified, radioactivity levels usually increase during transportation, especially for leaking assemblies.
\end{abstract}




\section{ACKNOWLEDGMENTS}

The authors express their appreciation for the many individuals and organizations who contributed constructive comments to this report. J. F. Fletcher provided guidance and direction of the study. F. E. Holt contributed the discussion of radiochemistry. It would not have been possible to assemble this data without the cooperation and interest of General Electric Morris Operation and the public utilities operating Point Beach, San Onofre, Haddam Neck and Big Rock Point nuclear power plants. 
Abstract

Acknow ledgments

Figures

vi

Tables

vi

1.0 SUMMARY

2.0 INTRODUCTION 3

2.1 Purpose 3

2.2 Scope 3

2.3 Definitions and Assumptions 5

2.4 Radioactivity Measurements 7

2.5 Corrosion Products 8

2.6 Reconciliation of Radioactive Species 9

2.7 Radioactivity Measurement Precision 11

3.0 CONCLUSIONS AND IMPLICATIONS 12

4.0 RECOMMENDATIONS 14

5.0 DISCUSSION OF FINDINGS 16

5.1 Transportation Effects 16

5.2 Transportation Versus Storage 21

5.3 Canning Needs $\quad 24$

5.4 Potential Degradation Mechanisms 25

5.5 Radioactivity Change Rates 28

5.6 Wet Versus Dry Shipments 31

5.7 Radioactivity Level Predictions 32

6.0 REFERENCES $\quad 35$

BIBLIOGRAPHY $\quad 35$

APPENDIX: Sumary of Shipping Data Assembled by HEDL A-1 


\section{FIGURES}

Figure

Page

2.1 Possible Method of Validating Absence of Spent Fue 1 Degradation During Transit

5.1 Comparison of Radioactivity Forecast with Actual After- 



\section{TABLES}

Table

Page

1.1 Summary of Investigated Spent Fuel Shipments 1

2.1 Comparison of Cesium Measurements Before Transport 10

5.1 Effects of Transportation 17

5.2 Comparison of Radioactivity Level After Transportation 18

5.3 Comparison of Radioactivity Transportation Increase 20

5.4 Comparison of Radioactivity Increase Ratio 22

5.5 Comparison of Transportation with Storage Radioactivity 23

5.6 Factors Influencing Radioactivity Level 24

5.7 Possible Degradation Mechanisms 26

5.8 Summary of Spent Fuel Transportation Mechanical
Environment

5.9 Radioactivity Change Rate 30

5.10 Comparison of Wet Versus Dry Shipments 32

A-1 Commercial LWR Fuel Shipped to Morris A-3

A-2 Commercial LWR Fuel Shipped to West Valley A-3

A-3 1976 Point Beach Shipment Data A-4

A-4 1977 Point Beach Shipment Data A-5

A-5 Selected San Onofre Shipment Data A-6

A-6 Selected Haddam Neck Shipment Data A-7

A-7 Selected Big Rock Point Shipment Data A-8 


\section{SPENT FUEL INTEGRITY DURING TRANSPORTATION}

\subsection{SUMMARY}

Data assembled in this report reveal no evidence that transportation contributes to cladding integrity loss of spent Light Water Reactor (LWR) fuel, nor could the data validate the absence of cladding integrity loss. A summary of the evaluated spent fuel shipments is shown in Table 1.1.

TABLE 1.1

SUMMARY OF SPENT FUEL SHIPMENTS INVESTIGATED

\begin{tabular}{|c|c|c|}
\hline From & To & Conditions \\
\hline $\begin{array}{l}\text { POINT BEACH - } 1 \text { PWR } \\
31 \text { Assemblies, } 1976 \mathrm{Zr}-\mathrm{Cl} \text { ad } \\
36 \text { Assemblies, } 1977 \mathrm{Zr}-\mathrm{Cl} \text { ad }\end{array}$ & $\begin{array}{l}\text { MORRIS, IL } \\
220 \mathrm{Mi}, 1 \text { day }\end{array}$ & Wet-Truck \\
\hline $\begin{array}{l}\text { HADDAM NECK - } 1 \text { PWR } \\
8 \text { Assemblies, } 1973 \text { SS-Clad } \\
6 \text { Assemblies, } 1974 \text { SS-Clad }\end{array}$ & $\begin{array}{l}\text { MORRIS, IL } \\
800 \mathrm{Mi}, 2-4 \text { days }\end{array}$ & Wet-Truck \\
\hline $\begin{array}{l}\text { SAN ONOFRE - } 1 \text { PWR } \\
7 \text { Assemblies, } 1977 \text { SS-Clad } \\
5 \text { Assemblies, } 1978 \text { SS-Clad }\end{array}$ & $\begin{array}{l}\text { MORRIS, IL } \\
1900 \mathrm{Mi}, 2-4 \text { days }\end{array}$ & Dry \& Wet-Truck \\
\hline $\begin{array}{l}\text { BIG ROCK POINT - BWR } \\
84 \text { Assemblies, } 1973 \mathrm{Zr}-\mathrm{Clad}\end{array}$ & $\begin{array}{l}\text { WEST VALLEY, NY } \\
750 \mathrm{Mi}, 2-3 \text { days }\end{array}$ & Wet-RaiT \\
\hline $\begin{array}{l}\text { TURKEY POINT - } 1 \text { PWR } \\
5 \text { Assemblies, } 1978 \mathrm{Zr}-\mathrm{Clad}\end{array}$ & $\begin{array}{l}\text { COLUMBUS, } \mathrm{OH} \\
900 \mathrm{Mi}, 2-3 \text { days }\end{array}$ & Dry-Truck \\
\hline
\end{tabular}

Although fission product levels or gross radioactivity increased in nearly all shipments for which before and after measurements were available, more than one source of these fission products prevents direct association of the radioactivity increase to cladding integrity loss. Although transfer of fission products from the fuel rod interior to the water coolant through breached cladding, fissures or pin holes may be the most obvious source, ion exchange or desorption of fission products from the corrosion products on the surfaces of the cladding was demonstrated. The absorbed fission products could be derived from adjacent leaking rods during storage or more likely during reactor service. 
Evaluation of data when radioactivity measurements were available before and after spent fuel shipment revealed no direct correlation with fuel burnup, cladding composition, transportation mode, or duration and distance of shipment.

The number of dry shipments of old spent fuel and the paucity of available definitive before-and-after measurements of cask coolant radioactivity seriously restrict the certainty of comparisons and conclusions. 


\subsection{INTRODUCTION}

\subsection{Purpose}

This report was prepared to contribute to the conceptual design of receiving facilities for spent fuel storage. The problem could be stated: "Can the absence of LWR fuel degradation during transportation from the reactor storage basin to interim field storage be demonstrated or validated with tangible data?" The answer to this question will determine the impact of spent LWR fuel on the operation of any receiving basin.

One alternative to shipping spent fuel to an interim storage basin is to relocate spent fuel to another reactor site storage basin to alleviate crowding. Since there is a shortage of operational interim storage basins, this variation in transportation operation is already in practice to meet the current discharge requirements of LWR systems.

\subsection{Scope}

Because of limited time available for this study, the scope had to be restricted to data that could be assembled and analyzed for a preliminary evaluation. Since data on mechanical damage were so limited, it was necessary to focus the study on cask coolant radioactivity measurements. Therefore, the assembled data were limited to that obtainable by expeditious telephone conversations, searches of available literature and personal visits.

Questions developed to define the problem of spent fuel integrity during transportation include:

1) How does transportation affect the integrity of spent LWR fuel?

2) How do transportation effects compare to storage effects?

3) Will canning requirements for a receiving facility be increased by radioactivity release during transportation? 
4) What degradation mechanisms caused by transport can be identified?

5) What radioactivity release rate occurs during transport?

6) How does dry shipping compare with wet?

Personnel safety is the first concern of facility operation. The need to avoid operational interruptions due to contamination in the event of radioactivity release from a fuel assembly cask into a controlled area upon unloading is an incentive for quantifying degradation. Mechanical cladding damage that contributes to radioactivity release is of concern. Mechanical damage that does not contribute to the rate of radioactivity release is secondary, because the fuel assemblies may be disposed of eventually in terminal geologic storage or chopped for ultimate reprocessing. The radioactivity levels of the cask exterior are not useful for cladding degradation evaluation. Establishing that Zircalloy is benign to storage water is a topic separate from that of transportation.

Comparing radioactivity measurement samples from cask coolant upon receipt prior to cask opening provides an opportunity for evaluating transportation integrity. However, this post-transport radioactivity measurement is more useful when compared to the extrapolation of at least two radioactivity measurements from the cask coolant prior to transporting.

Fuel assemblies with a history of radioactivity release (known as leakers) may intentionally be included in shipment lots. These leaking assemblies may affect the normal radioactivity levels inside the cask both before and after shipment. Therefore, shipments containing leakers should be compensated for in the evaluation of transport integrity. Furthermore, possible trends of fuel behaviors in future LWRS need consideration as fuel cycle economic considerations demand longer fuel life and increased burnup.

The approach applied to solve the transport integrity question involved the following steps: 
- Identify shipments that can be analyzed. First, find the utilities that have completed spent fuel shipments. Second, identify specifics of each shipment including: 1) reactor and cladding type; 2) the number of similar lots; 3) spent fuel condition and burnup; and 4) history of leakers.

- Identify conditions of shipments (most recent first) including dates, duration, mileage, transport mode (rail vs truck), and coolant (water, air, or inert gas).

- Obtain fuel assembly radioactivity measurements: 1) as discharged (usualiy sipping): 2) prior to shipment after cask loading and closure (more than one measurement, if available); 3) after receipt at destination but prior to cask opening; and 4) receiving basin coolant radioactivity change.

- Establish the pre-shipment radioactivity trend to predict radioactivity level expected upon receipt as idealized in Figure 2.1. Establish the normal trend of this extrapolation compared to posttransport in-cask measurement. Determine the number and significance of any abnormal statistical deviations.

The Code of Federal Regulations ${ }^{(1)}$ establishes $10^{-7} \mathrm{Ci} / \mathrm{ml}$ radioactivity for Group I nuclides to be an acceptable limit for cask coolant. General Electric Morris Operation uses $0.3 \times 10^{-7} \mathrm{Ci} / \mathrm{ml}$ radioactivity as an acceptance level of cask coolant prior to shipping.

\subsection{Definitions and Assumptions}

Degradation is defined, for the purposes of this report, as any mechanism that results in the loss of integrity of the fuel assembiy, such as corrosion, crack propagation or crack initiation which penetrates the cladding or supporting structures of the fuel assembly. 


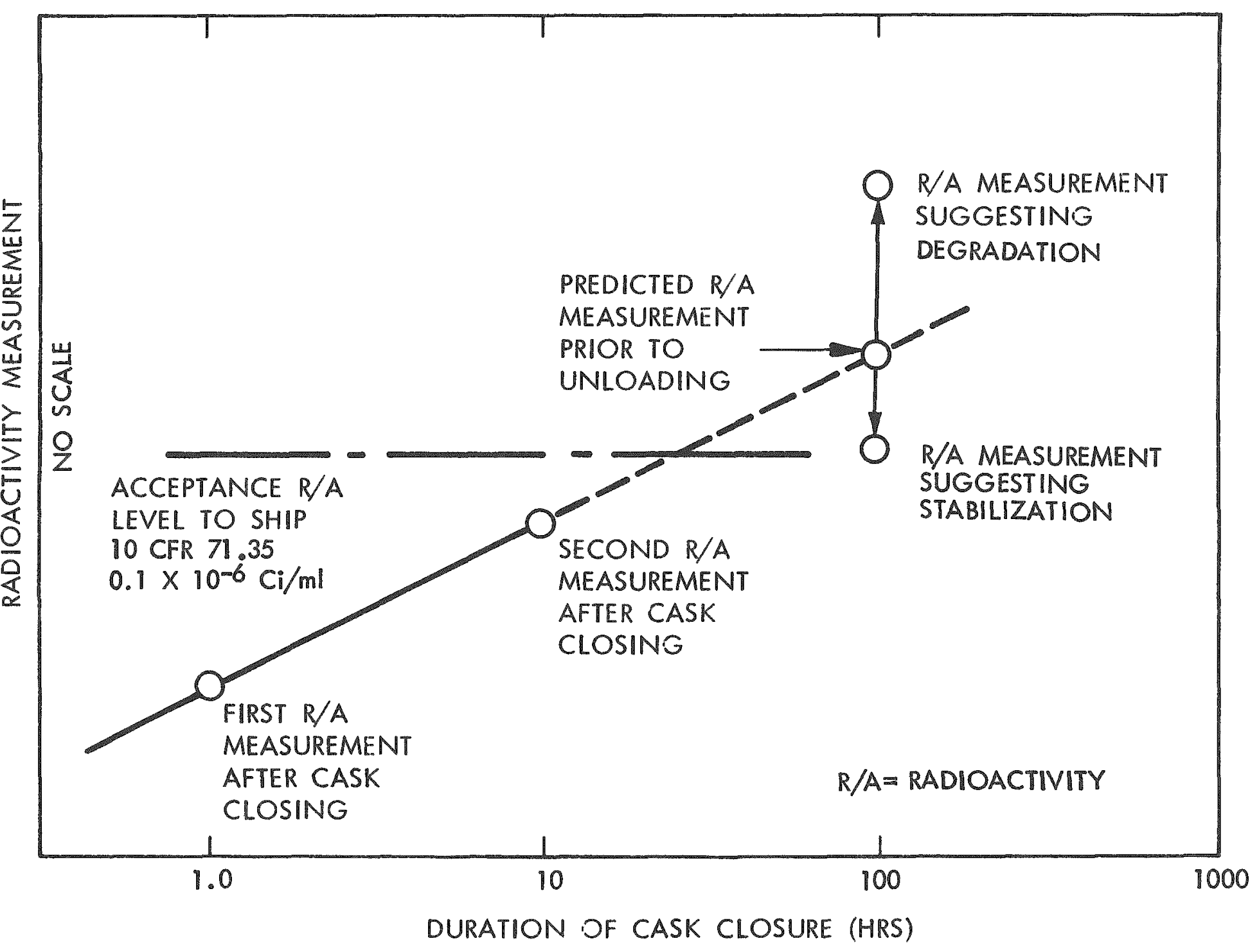

HEDL. 7805-308.2

FIGURE 2.1. Possible Method of Validating Absence of Spent Fuel Degradation During Transit. 
Although the linear functions of the radioactivity level or concentration changes are assumed, this was the only basis available within the scope of this assignment.

\subsection{Radioactivity Measurements}

For assemblies shipped in water-filled casks, the analysis of the cask water for ${ }^{137} \mathrm{Cs}$ is useful. Cesium migrates toward the periphery or co01est part of a fuel element. Therefore, the highest concentration would be in the region next to the cladding where the cesium could be leached into the water from fuel elements having breached cladding. Cesium reacts with water to form $\mathrm{H}_{2}$ and $\mathrm{CsOH}$. Presumably, some $\mathrm{CsCl}$ would also be present, if chloride ions were in the water. Both $\mathrm{CsOH}$ and $\mathrm{CsCl}$ are soluble in water. Cesium born in a fuel element may be present at the periphery as CSI which is much less soluble in cold water but reasonably soluble in warm $\left(61^{\circ} \mathrm{C}\right)$ water. $(2)$

For casks filled with air, the mass spectrometric analysis of grab samples for stable $\mathrm{Kr}$ and $\mathrm{Xe}$ could be used to indicate cladding integrity. The grab samples could be taken in an evacuated cylinder, or they could be absorbed onto a charcoal trap through which air is drawn. The fission yields of the stable $\mathrm{Kr}$ and $\mathrm{Xe}$ isotopes of interest are: ${ }^{86} \mathrm{Kr}, 2.0 \%$; ${ }^{134} \mathrm{Xe}$, $8.1 \% ;{ }^{136} \mathrm{Xe}, 6.5 \%$. An analysis prior to and after shipping could confirm that the fuel cladding was intact. Since there is some natural $\mathrm{kr}$ and $\mathrm{Xe}$ in the air, ratios of ${ }^{136} \mathrm{xe} /{ }^{130} \mathrm{Xe}$ or ${ }^{86} \mathrm{Kr} /{ }^{82} \mathrm{Kr}$, would probably be needed to determine the presence of fission gas from a fuel element with breached cladding.

The same grab samples could be analyzed for radioactivity. Although not as sensitive, the analys is would be more rapid than mass spectrometry. For this technique, samples would have to be trapped onto charcoal, probably at 
a reduced temperature $\left(20^{\circ} \mathrm{F}\right.$ or less), in order to obtain enough Krypton samples. The presence of ${ }^{85} \mathrm{Kr}$ could indicate a cladding breach. Krypton-85 has a low fission yield $(0.3 \%)$, long half-life (10 years), and a very low gamma ray abundance $(0.4 \%)$. Consequently a large-sized sample would be required.

\subsection{Corrosion Products}

Reactor system corrosion products deposit as "crud" on fuel assemblies. These deposits can shake loose from fuel assembly surfaces and contribute radioactivity to the post-transported sample of cask coolant or flush solutions. The isotopes usually found in crud deposits after a cooling period of 120 days or more are:

$\begin{array}{ll}\text { Isotope } & \text { Half } \text { - Life } \\ { }^{60} \mathrm{Co} & 5 \text { years } \\ { }^{54} \mathrm{Mn} & 300 \text { days } \\ { }^{65} \mathrm{Zn} & 245 \text { days }\end{array}$

Recent experience at General Electric Morris Operation shows the relative contribution of cobalt to the total storage pool radioactivity level to be increasing as 1) the quality of the spent fuel improves, 2) there is less fission product leakage and 3) improved methods of removing the concentration of radiocesium from pool water are implemented. The film of corrosion products present on the surface of the spent fuel cladding provides a reservoir for holding impurities, including fission products such as cesium.

The Morris Plant has demonstrated that nonradioactive cesium replaces ${ }^{137}$ Cs contained in the crud. The deposit appears to have ion exchange-like properties. This raises the possibility that ${ }^{137} \mathrm{Cs}$ in the cask coolant can be contributed to by residual ${ }^{137} \mathrm{Cs}$ in the cask or reactor basin, or platedout ${ }^{137}$ Cs from adjacent leaking fuel assemblies during reactor service as well as fission products leaking through breached cladding. 


\subsection{Reconciliation of Radioactive Species}

Comparison of different reported species of radioactivity was attempted by tabulating the San Onofre data in Table 2.1. San Onofre data provide the most complete information of fission products with determined errors and under a variety of conditions. Radioactivity levels of a single assembly ( $C$-46) were first compared. This assembly had been identified as a known leaker. The measurements were made with the same apparatus, burnup and reactor exposure. The only difference in the measurements was the two-hour sampling intervals. The first sample was not included in the analysis because it was taken at time zero before the radioactivity in the cask coolant became homogeneous.

The measured ratio of ${ }^{137} \mathrm{Cs}$ to ${ }^{134} \mathrm{Cs}$ ranged from 3.27 to 3.56 with an average of 3.38 . The ratio of the ${ }^{137}$ Cs to the total Cs $\left({ }^{137} C_{S}+{ }^{134} \mathrm{Cs}\right)$ for the same group of samples ranges from 0.766 to $0.788 \mu \mathrm{Ci} / \mathrm{ml}$, averaging 0.77 . Although the total Cs values increase with time (since they are accumulating), no specific trend can be found for the ${ }^{137} \mathrm{Cs} /{ }^{134} \mathrm{Cs}$ ratio or for the fraction that ${ }^{137} \mathrm{Cs}$ is of the total Cs.

Comparison of other measurements is possible for five different San Onofre assembiies. Although the sampling and measurement methods are the same, there is no assurance of the consistency of the age of the assemblies or their burnup.

The ${ }^{137} \mathrm{Cs} /{ }^{134} \mathrm{Cs}$ ratio was found to range from 1.4 to 4.56 , with an average of 3.0 for the assemblies for which sample data were available. The ratio is low for radiocesium derived from fuel that is of high burnup and/or short cooling (from time of discharge) and high for radiocesium derived from fuel that is of low burnup and/or long cooled. Assembly $\mathrm{C}-28$, with a ratio of 4.56 , had nearly a five-year cooling time whereas assemblies D-36 and D-39 experienced an approximate 28-month cooling time. 
TABLE 2.1

COMPARISON OF CESIUM MEASUREMENTS BEFORE TRANSPORT $(\mu \mathrm{Ci} / \mathrm{ml})$

\begin{tabular}{|c|c|c|}
\hline $\begin{array}{l}\text { San Onofre } \\
\text { Fuel Assembly }\end{array}$ & ${ }^{137} \mathrm{Cs}$ & $134 \mathrm{cs}$ \\
\hline $\begin{array}{c}* \times C-46 \\
11 \\
" 11 \\
11 \\
11 \\
11 \\
11 \\
11 \\
11 \\
11 \\
11 \\
11 \\
" 1\end{array}$ & $\begin{array}{l}0.498 \\
0.861 \\
0.890 \\
0.899 \\
0.877 \\
0.883 \\
0.959 \\
0.957 \\
0.978 \\
0.908 \\
0.913 \\
0.980 \\
0.989\end{array}$ & $\begin{array}{l}0.0001 \\
0.245 \\
0.267 \\
0.276 \\
0.270 \\
0.270 \\
0.270 \\
0.271 \\
0.275 \\
0.278 \\
0.280 \\
0.281 \\
0.284\end{array}$ \\
\hline $\begin{array}{l}C-21 \\
C-28 \\
C-47 \\
D-36 \\
D-39 \\
D-42 \\
E-19 \\
E-22 \\
E-40\end{array}$ & $\begin{array}{l}0.0305 \\
0.1185 \\
0.0065 \\
0.0007 \\
0.0015 \\
0.0001 \\
0.0001 \\
=\end{array}$ & $\begin{array}{c}0.0082 \\
0.026 \\
0.0020 \\
0.0005 \\
0.0008 \\
- \\
- \\
- \\
-\end{array}$ \\
\hline
\end{tabular}

\begin{tabular}{l}
$137 C s / 134 C s$ \\
\hline $3414.2 *$ \\
3.51 \\
3.33 \\
3.26 \\
3.25 \\
3.27 \\
3.55 \\
3.53 \\
3.56 \\
3.27 \\
3.26 \\
3.26 \\
$\frac{3.48}{20.53}=3.38$ \\
$\frac{12}{12} \quad$ avg
\end{tabular}

3.72

4.56 01d Fuel 3.25

1.4 New Fuel

1.88 New Fue]
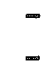

$$
\sum \overline{\frac{14.81}{5}}=3.0
$$

\begin{tabular}{|c|c|}
\hline$(137 c s+134 c s)$ & $137 c_{s} /\left(137 c_{s}+134 c_{s}\right)$ \\
\hline $\begin{array}{l}0.499 * \\
1.106 \\
1.157 \\
1.175 \\
1.147 \\
1.153 \\
1.229 \\
1.228 \\
1.253 \\
1.186 \\
1.194 \\
1.193 \\
1.261\end{array}$ & $\begin{array}{l}0.999 \\
0.788 \\
0.769 \\
0.765 \\
0.765 \\
0.766 \\
0.780 \\
0.779 \\
0.781 \\
0.766 \\
0.765 \\
0.777 \\
0.777 \\
\end{array}$ \\
\hline$\sum \frac{14.282}{12}=1.19$ & $\sum \frac{9.278}{12}=0.77$ \\
\hline
\end{tabular}

0.788

0.818

0.765

0.583

0.653

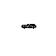

$-$

$-$

* = Omit from total because sample time too short.

t* = Identified leaker: measurements taken at 2-hour intervals. 
Since test comparisons are for several conditions of the same lot of fuel assemblies, it appears reasonable that the ${ }^{137} \mathrm{Cs}$ ratio is between 0.62 and 0.77 . However, the ratio of ${ }^{137} C_{S}$ is directly influenced by burnup and decay time. Therefore, reconciliation of ${ }^{137} C_{S}$ to total Cs will not have an accuracy of better than $\pm 1 / 2\left[\frac{0.77-0.62}{0.62}\right]$ or $\pm 12 \%$ without additional correlation of exposure.

\subsection{Radioactivity Measurement Precision}

The degrees of precision of both sampling and measurement of radioactivity were examined for the two available cases. San Onofre provided direct instrument readout of errors for each radioactivity measurement. These results show that the specific ${ }^{137} \mathrm{Cs} \mu \mathrm{Ci} / \mathrm{ml}$ of cask coolant ranged from 0.21 to 19.4 for each reading. However, this amounts to less than $0.00225 \mu \mathrm{Ci} / \mathrm{ml}$ and an average of $0.0013 \mu \mathrm{Cj} / \mathrm{ml}$ for 22 readings.

Results from Big Rock Point show some negative changes in the radioactivity level which have been attributed to the error of sampling and measurement. The worst case of negative change, that of $4.34 \mu \mathrm{Ci} / \mathrm{ml}$, would yield a 96 percent error. These differences are attributable to changes in instrumentation between reactor site and receiving basins. 


\subsection{CONCLUSIONS AND IMPLICATIONS}

The conclusions developed from the investigation are presented, together with some discussion of their implications.

1) Integrity loss of spent LWR fuel has neither been found nor has its absence been validated. (See Section 5.1.)

However, radioactivity levels in cask coolant consistently increase in nearly all shipments from which before and after measurements were available. The radioactivity increase usually found after transportation appears to support migration of fission products from the fuel rod interior to the cask coolant. While this migration could occur through fissures in cladding, it could also be caused by ion exchange of fission products absorbed on the corrosion crud type deposits found on the rod exteriors.

Although mechanical damage from over-the-road shock and vibration was postulated, no reports of evidence of this mechanism were found by this investigation. However, normal shipping practices do not include visual inspection or more sophisticated tests to determine the condition of spent fuel before or after transportation. The unexplored mechanical mechanism of the propagation of incipient fissures could possibly be a contributor to the increased radioactivity during transportation.

2) The rate of radioactivity change was found to be positive in nearly a.ll shipment populations. (See Section 5.5.)

The Tevels of the exceptions were so small that measurement or sampling errors could explain the anomaly. Periodic measurements on one specific leaking assembly every two hours demonstrated that $87 \%$ of the 24-hour radioactivity increase occurred during the first two hours of the series of samples. This suggests that the migration of fission products from the rod to the cask coolant is very nearly 
complete in the first two hours, at least for this configuration of defect. As expected, the radioactivity level increase and rate of change were greater for assemblies with a history of leaking.

3) Canning requirements are not increased beyond acceptable levels by observed radioactivity increases during transportation under the current Morris imposed acceptance criteria. (See Section 5.3.)

However, acceptance of grossly damaged spent fuel could increase coolant radioactivity levels beyond that allowed by current practice, so that canning would become desirable.

4) Cask coolant radioactivity levels after transportation were found to be larger than those of receiving basins. (See Section 5.2.)

The volumetric dilution $(40,000: 1)$, near continuous purification, the settling of particulates and generally lower temperatures of receiving basins contribute to this.

5) The population of usable data was limited. (See Section 5.1.)

The number of useful shipments with radioactivity measurements complete enough for comparison ranged from 24 shipments in one case down to two. Although other data blocks exist, they could not be assembled, organized and evaluated in this time frame of the investigation.

6) Correlations of transportation effects could not be found for burnup, cladding alloy composition, storage duration, transport distance, dry versus wet shipping media, transportation mode shock or vibration loads. (See Section 5.1.)

7) The radioactivity levels of spent fuel after transportation, including most leakers, are so low that they have no major impact on the operation of a receiving basin. (See Section 5.2.) 


\subsection{RECOMMENDATIONS}

The following tasks are recommended for future work:

1) Reconcile the different species of radioactivity measurements to better define the implications for more accurate comparisons of different sample lots.

2) Locate and evaluate additional shipment radioactivity data to broaden the data base and improve statistical analysis.

3) Identify the influence of cask contamination to compensate radioactivity measurements for residual contaminants from prior shipments, corrosion products from the reactor system, fission products from adjacent leading assemblies during reactor service, and storage pool coolant residues. This should include tests of coolant-filled casks returned over the road empty of fuel assemblies to evaluate the contribution of over-the-road agitation of residual contamination.

4) Attempt to forecast the change of cask coolant radioactivity level to identify over-the-road radioactivity contribution and the subsequent contribution to receiving basin purification system capacity requirements.

5) Conduct over-the-road tests with irradiated high burnup fuel assemblies with before and after examinations to demonstrate the mechanical integrity of high burnup assemblies with potential incipient leakers. An alternative would be vibration tests programmed to over-the-road conditions. 
6) Prepare a standard with criteria to assure consistent and comparable radioactivity measurement of spent fuel before and after transportation.

7) If degradation during transportation is found to be significant, recommend methods to minimize its impact. 


\subsection{DISCUSSION OF FINDINGS}

\subsection{Transportation Effects}

Transportation of spent LWR fuel increases the level of radioactivity in cask coolant water. Measurements of shipments from four power plants are shown in Table 5.1. Data from additional plants were investigated but had insufficient measurements recorded to be of value.

The maximum radioactivity found in cask coolant water after transport in Table 5.2 provides the basis for the initial comparison, which shows the effects of transportation on spent LWR fuel. Table 5.2 develops the following findings:

1) The radioactivity level in Table 5.2 is larger for fuel assemblies identified as having a history of leaking radioactivity. The ratio of radioactivity level increase for leakers to that for non-leakers is 500 times greater for San Onofre and 20 times greater for Point Beach fuel assemblies.

2) Neither the cask coolant media (demineralized water or air) nor the cladding alloy (SS or $\mathrm{Zr}-4$ ) shows any trends of radioactivity level in cask coolant after transportation. See Table 5.2.

3) The population of the available specific lots of shipments shown in Table 5.2 limits the statistical significance that can be applied to these trends. The different species of radioactivity $\left({ }^{137} \mathrm{Cs}\right.$ and gross beta) measured in cask coolant introduce uncertainty in the comparisons, even though the units are equivalent $(\mu \mathrm{Ci} / \mathrm{ml}$ of fluid).

4) The significance of the level or amount of the maximum radioactivity found in cask coolant after transportation (Table 5.2) is not clear. The impact of this radioactivity level on the 
TABLE 5.1

EFFECTS OF TRANSPORTATION

\begin{tabular}{|c|c|c|c|c|c|c|c|}
\hline \multirow{3}{*}{$\begin{array}{l}\frac{\text { Conditions }}{\text { POINT BEACH }- \text { MORRIS } 1976} \\
\frac{\text { (PWR: } Z r-4)}{}\end{array}$} & \multirow{3}{*}{$\begin{array}{l}\text { No. of } \\
\text { Shipments }\end{array}$} & \multicolumn{5}{|c|}{ Radioactivity (uCi/ml) } & \multirow[b]{2}{*}{ Species } \\
\hline & & \multicolumn{2}{|c|}{$=($ CCAT $)$} & \multicolumn{2}{|c|}{$\frac{(\text { CCAT-CCBT) }}{1}$} & \multirow[t]{2}{*}{ (CCAT/CCBT) } & \\
\hline & & $\max$ & avg & $\max$ & avg & & \multirow{3}{*}{${ }^{137} \mathrm{Cs}$} \\
\hline Leakers - wet & 2 & 0.130 & 0.111 & 0.129 & 0.110 & 164 & \\
\hline Non-Leakers - wet & $24-34$ & 0.0066 & 0.00206 & 0.0057 & 0.0019 & 6.9 & \\
\hline \multicolumn{2}{|l|}{$\frac{\text { SAN ONOFRE }}{\text { (PWR: }}$ SS) } & & & & & & ' \\
\hline Leakers - dry & 5 & 1.10 & 0.42 & 1.11 & 0.42 & 0.16 & Total Cs \\
\hline Non-leakers - wet & 2 & 0.00075 & 0.00056 & 0.00027 & $n / 2$ & negative & $"$ \\
\hline$-d r y$ & 5 & 0.0021 & 0.00055 & 0.00137 & .00089 & 16.2 & $"$ \\
\hline \multicolumn{8}{|c|}{$\frac{\text { HADDAM NECK }}{(\text { PWR... })}-$ MORR IS 1973-1974 } \\
\hline Non-Teakers - wet & 2 & 0.58 & 0.35 & 0.119 & 0.289 & 0.119 & gross \\
\hline \multicolumn{8}{|l|}{ BIG ROCK POINT } \\
\hline Non- \& Leakers - wet & 5 & 1.8 & - & 0.09 & - & - & gross \\
\hline
\end{tabular}


TABLE 5.2

COMPARISON OF RADIOACTIVITY LEVEL AFTER TRANSPORTATION

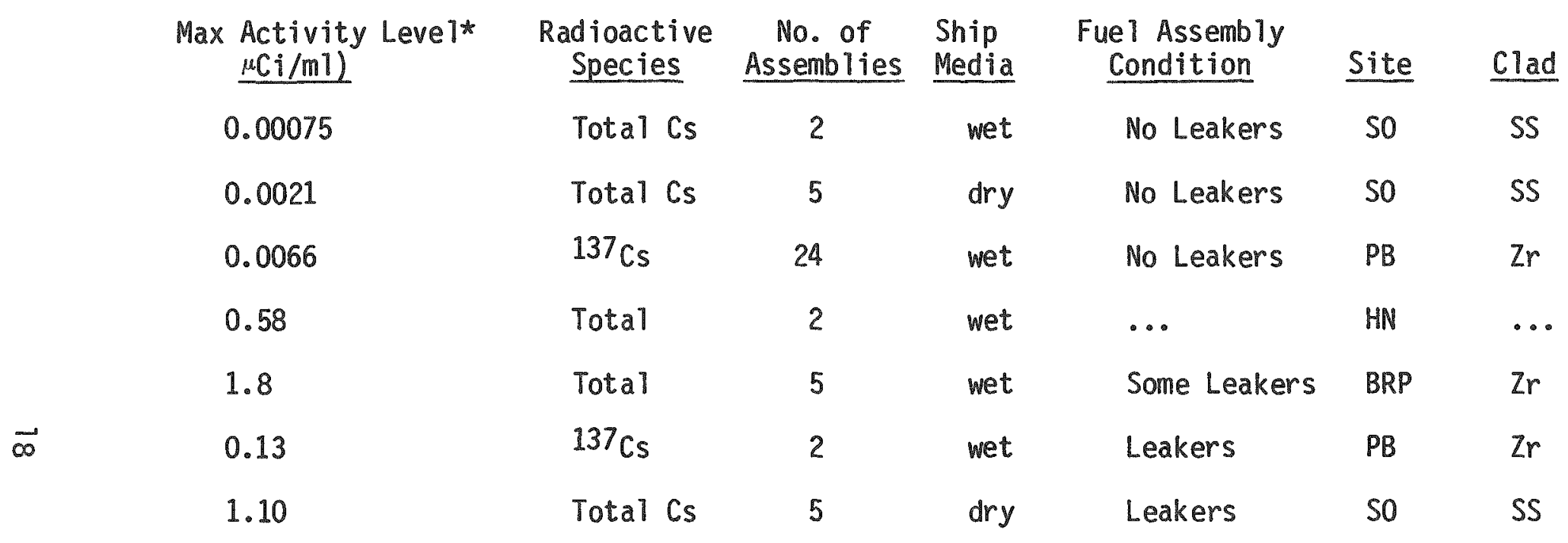
$S O=\operatorname{San}$ Onofre
$\mathrm{PB}=$ Point Beach
HN = Haddam Neck
BRP $=$ Big Rock Point

* Deionized cask shipped or rinse water for dry shipments. Sampling methods may not be standardized. 
radioactivity level of the receiving basin is increased by the accumulation of the radioactivity load and by each fuel assembly transferred to the basin, and by diffusion of fission products through the breached or leaking cladding into the cooling media of the cask or storage basin. The impact of the radioactivity in cask coolant after transport is decreased by the dilution ratio of the receiving bas in volume to that of the cask $(40,000: 1$ for the Morris Basin and IF 300 cask) and the progressive removal of radioactivity from the receiving basin by the coolant purification system. (1)

5) Comparisons of BWR shipments from Big Rock Point in Tables 5.1 and 5.2 show no significant trends.

The most direct index of transportation effects is the comparison of radioactivity measurements before and after radioactivity shipment shown in Table 5.3, which provides the following findings:

1) The known leaking fuel assemblies show the largest radioactivity increase, by as much as 4 orders of magnitude.

2) Although there are very few cases to compare at this time, the increase in radioactivity levels for dry shipment was six times greater than that of wet non-leaking shipments from the same plant. Although large differences of radioactivity changes appear between SS clad leakers and non-leakers, these changes could be altered by the configuration of the cladding breach and the exposure conditions of burnup, storage duration, transportation duration, and mechanical shock and vibration.

3) Few shipments of BWR spent fuel show an increase in radioactivity level (see Table 5.3). 
TABLE 5.3

COMPARISON OF RADIOACTIVITY TRANSPORTATION INCREASE

(After-Transport Measurement Less Before-Transport Measurement)

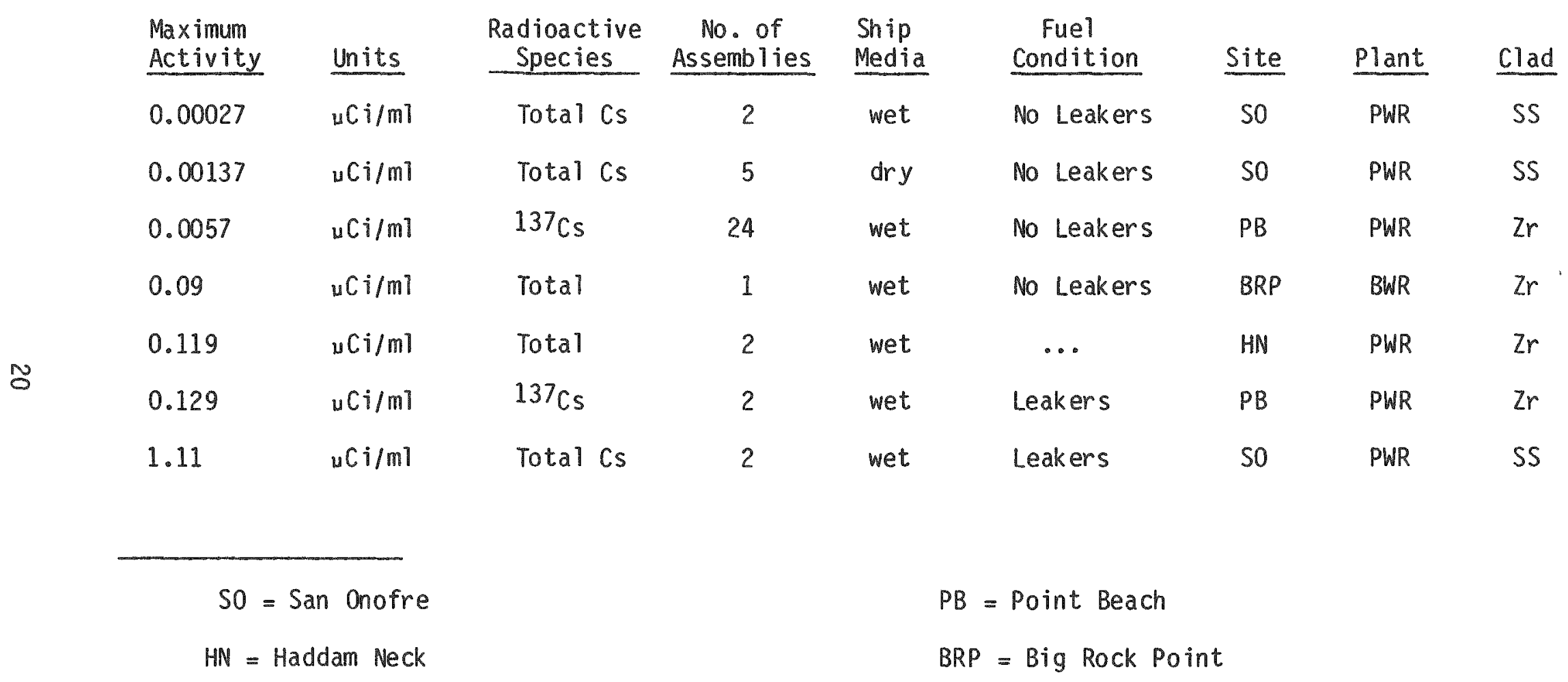


The ratio of radioactivity increase in cask coolant to the radioactivity level of the cask coolant before transportation, shown in Table 5.4, normalized for the level of radioactivity, shows:

1) The radioactivity ratio is as great as 164 for one leaking Point Beach fuel assembly. The ratio for non-leaking Point Beach fuel assemblies is 6.9 for a population of 24 fuel assemblies over the same route of 220 miles in a wet truck cask for a duration of approximately one day.

2) In contrast, the ratio is 0.16 for leaking and 16.2 for nonleaking dry San Onofre shipments over the same route of 1900 miles in a wet truck cask for about four days. However, the values (16.2 for dry, and negative ratio for wet non-leaking) are so small that either sampling or measurement errors probably best explain this anomaly.

3) Since the ratio of 0.08 in Table 5.4 represents only one of five shipments for which completed data were available, the contribution of the BWR Big Rock Point data does not alter previous findings.

\subsection{Transportation Versus Storage}

Comparison of the ${ }^{137}$ Cs radioactivity level of coolants in Table 5.5 shows that the normal level in shipping casks after transportation 10.002 $\mu \mathrm{Ci} / \mathrm{ml})$ is five times greater than the normal radioactivity level of the receiving basin at Morris $(0.0004 \mu \mathrm{Ci} / \mathrm{ml})$. Comparison of the maximum coolant radioactivity levels in Table 5.5 also shows shipping cask coolant after transportation $\left(1.1 \mu \mathrm{Ci} / \mathrm{ml}{ }^{137} \mathrm{Cs}\right)$ to be greater than that of the maximum radioactivity level of the receiving basin at Morris $(0.003 \mu \mathrm{Ci} / \mathrm{m} 1)$.

Comparing the relatively short transportation time (one to four days) with the extended storage time (up to approximately ten years), the opportunity for an increase in the radioactivity level would appear to be significantly greater during spent fuel storage than during spent fuel transport. 
TABLE 5.4

COMPARISON OF RADIOACTIVITY INCREASE RATIO

\begin{tabular}{|c|c|c|c|c|c|c|}
\hline $\begin{array}{l}\text { Increase Ratio* } \\
(\mu \mathrm{Ci} / \mathrm{ml}) \\
\end{array}$ & $\begin{array}{l}\text { Radioactive } \\
\text { Species }\end{array}$ & $\begin{array}{c}\text { No. of } \\
\text { Assemblies }\end{array}$ & $\begin{array}{l}\text { Ship } \\
\text { Media }\end{array}$ & $\begin{array}{l}\text { Fuel Assembly } \\
\text { Condition } \\
\end{array}$ & Site & Clad \\
\hline Negative & Total Cs & 2 & wet & No Leakers & so & SS \\
\hline 0.08 & Total & 9 & wet & Some Leakers & BRP & $\mathrm{Zr}$ \\
\hline 0.119 & Total & 2 & wet & $\ldots$ & $H N$ & $\mathrm{Zr}$ \\
\hline 0.16 & Total Cs & 5 & dry & Leakers & so & SS \\
\hline 6.9 & ${ }^{137} \mathrm{Cs}$ & 24 & wet & No Leakers & PB & $\mathrm{Zr}$ \\
\hline 16.2 & Total Cs & 5 & dry & No Leakers & So & SS \\
\hline 164.0 & ${ }^{137} \mathrm{Cs}$ & 2 & wet & Leakers & PB & $\mathrm{Zr}$ \\
\hline
\end{tabular}

*Ratio is defined as follows: $\frac{A T-B T}{B T}$

where: AT - radioactivity measurement after transport BT - radioactivity measurement before transfer

SO $=$ San Onofre

$\mathrm{PB}=$ Point Beach

$H N=$ Haddam Neck

$B R P=$ Big Rock Point 
TABLE 5.5

COMPARISON OF TRANSPORTATION WITH STORAGE RADIOACTIVITY

\begin{tabular}{ccc} 
Concentration & Total \\
$(\mu \mathrm{Ci} / \mathrm{ml} 137 \mathrm{Cs})$ & Radioactivity \\
\hline
\end{tabular}

TRANSPORTATION

$\begin{array}{lccc}\text { IF } 300 \text { (Rail Cask) } & \ldots & 3.75 \times 10^{6} & \ldots \\ \text { Normal (San Onofre) } & 0.002 & \ldots & 0.0075 \\ \text { Maximum (San Onofre) } & 1.1 & \ldots & 3.6\end{array}$

$\stackrel{N}{\omega}$

STORAGE (Receiving)

Morr is

$\begin{array}{lcc}\ldots .0004 * & 153,300 \times 106 * * * & \cdots \\ 0.003 * * & \ldots & 0.95 \\ & \ldots & 7.13\end{array}$

*Source NEDO - 21837

$\frac{153300 \times 10^{6}}{3.75 \times 10^{6}}=40,900 \quad$ Dilution Factor

*operating Chart

***77-JPGC-HE-15 ASME 
However, the ratio of the volume of the away-from-reactor (AFR) storage basin coolant to the volume of the shipping cask coolant greatiy dilutes the radioactivity concentration. The AFR storage facilities have coolant purification systems that are continually removing radioactivity from the basin coolant. In addition, the samplings of the cask coolant for the San Onofre fuel assembly $\mathrm{C}-46$ taken at two hour intervals indicate that the largest fraction of the radioactivity diffusion, for leaking fuel at least, occurs during the first two hours of exposure to fresh coolant and a different storage medium.

Factors influencing the radioactivity level are compared in Table 5.6. The descending order of significance for storage or transportation is: 1) volume of the casks and basins; 2) duration of the exposure; 3) time for compositions of the coolants to homogenize or come to equilibrium; and 4) the undetermined magnitude of impurity removal from the receiving basin.

TABLE 5.6

FACTORS INFLUENCING RADIOACTIVITY LEVEL

\section{Transportation}

Duration (days)

Coolant Volume $\left(\mathrm{m} 1 \times 10^{6}\right)$

Rate Stabilization ( $h r$ )

Purification
$1-4$

3.75

2

none
Storage

$120-3650$

2377

200

decreases

\subsection{Canning Needs}

Increases in the radioactivity level of cask coolant water during transportation have not been sufficient to require canning or isolation of spent LWR fuel assemblies. 
The Morris Facility has been relatively trouble-free due to the application of a specific acceptance level of radioactivity prior to shipping $(0.03 \mu \mathrm{Ci} / \mathrm{ml}$ of cask coolant). In addition, the plant has an adequate capacity to purify the radioactive species by filtration and ion exchangers. In contrast, the older design West Valley basins have been less fortunate because of the absence of the preshipping restriction and the breached condition of much of the non-commercial fuel received. Hindsight suggests that the West Valley operation might have used canning to prevent considerable contamination problems and clean-up campaigns.

Another consideration that may affect canning requirements is the possibility that government controlled interim storage basins could be required to accept fuel in a 11 stages of deterioration. If such an event occurs the current practice of avoiding the canning of leaking fuel assemblies may have to be changed. One approach to counter this possibility would be the intentional over-design of purification systems. Indeed, such over-design could reduce the cost of operational cleanup campaigns.

Canning requirements appear to be more directly affected by the integrity of the fuel assemblies as discharged from the reactor than by the additional radioactivity that might occur during the transportation operation.

\subsection{Potential Degradation Mechanisms}

Potential failure modes of spent LWR fuel have been classified in Table 5.7. Transportation has been considered to include cask loading and unloading. This evaluation excludes those operational stages and focuses on actual transit (that time between cask closing and opening). This of course excludes such possible handiing incidents as dropping a full assembly under water in a reactor or storage basin. 
TABLE 5.7

POSSIBLE DEGRADATION MECHANISMS

Operational Stage

\begin{tabular}{lll}
\hline Loading & Transit & Unloading \\
\hline Chemical Corrosion & \\
Liquid Water & \\
Wet Air & Handling Drop \\
\hline Handling Drop & Mechanical & \\
Shock & \\
Vibration Clad Support Structures & \\
& - Clad Crack Propagation
\end{tabular}

Note: Although it is not an actual failure mechanism, agitation of crud in cask fluid contributes to radioactivity level measurements and background contaminations.

Consider, then, the chemical mechanisms that may contribute to degradation affecting radioactivity measurements. Cladding corrosion in high purity water over the short duration of shipping (less than a week for domestic and less than a year for export cargos) is insignificiant at room temperature for the cladding and structural alloys used in fuel assemblies. Temperatures of less than $212^{\circ} \mathrm{F}$ should not increase the rate of corrosive attack. High temperature and radiation fluence of reactor service causes 
major alterations to fuel pellets and may, to a lesser extent, alter properties and the structural integrity of cladding. However, prolonged ( 1 to 10 year) storage in water basins near ambient temperature limits the changes to leaching processes of solubles through already existing fissures.

Since no case was found that identifies radioactivity leakage from a Zircaloy-clad fuel rod in water storage, it appears safe to reduce emphas is on chemical alteration in storage. However, reactor service may entail several mechanisms that can rupture cladding. These include hydriding, mechanical or thermal stress, and pellet-clad interaction (PCI), deformation, bowing, and internal clad oxidation by oxide fuel or exterior oxidation by water reactions. Chemical reaction of dissimilar alloys can cause galvanic attack. Various combinations can develop cracks that partially or completely penetrate the cladding. These potentially degrading factors, however, are recognized and allowed for in the safety factors applied to fuel assembly designs.

Transit degradation of breached or leaking spent fuel assemblies would involve a process of water entering the cladding and transporting solubles or particulates to the cask fluid. This would increase the concentration of radioactive isotopes in the cask water. The stability change in radioactivity level during transit suggests a measurement that may make it possible to validate the absence of degradation during transit.

Mechanical shock and vibrations over a longer duration apply loads that may propagate cladding defects. Whether the shock or vibration loads and frequencies are sufficient actually to propagate cracks depends on a combination of load magnitudes and sizes of fuel assembly rod defects. Since corrosion damage is unlikely during transportation, mechanical damage would probably be the major cause of breaching of clad integrity that may occur in some shipments. Moreover, mechanical damage is a cumulative process and would provide the major contribution to crack propagation and loss of integrity during transportation and later in interim storage. However, this study did not find any direct evidence that the shipped spent fuel assemblies did or did not suffer damage during shipment. 
The magnitude of over-the-road shock and vibration has been estimated for transportation on a comparative bas is in Table 5.8. Such comparisons show rail transport to have greater shock and vibration loads than trucks. Recent application of new air suspension systems to truck cask trailers are reported to have reduced the shock and vibration levels as much as ten-fold.

\subsection{Radioactivity Change Rates}

The change rate of radioactivity measurements is significant, because it may relate to the rate of transfer of fission products from the fuel rod interior to the cask coolant, and these rates could provide an approach for extrapolating activity levels with time. Measurements for estimating activity level change rate were found for three sets of conditions. Although sampling times are not consistently available, it was possible to estimate the times from route distances with enough accuracy so that radioactivity change rates could be compared.

Comparison of the radioactivity change rate for spent fuel shipments for different reactors (see Table 5.9) shows that leaking fuel assemblies have rates greater than those of non leakers $(0.004-0.009$ compared to $0.00006-0.000006 \mu \mathrm{Ci} / \mathrm{ml}-\mathrm{hr}$ ), as would be expected. No apparent correlations were found for the radioactive species, cask media, cladding alloy or reactor design.

Examination of radioactivity change rates for ten Big Rock Point spent fuel shipments before transportation (Table 5.9) shows rates approaching those of the leakers. The Big Rock Point shipments contained from 6 to 10 fuel assemblies per cask and were confirmed to have from 4 to 7 known leaking fuel assemblies in each cask shipment. 
TABLE 5.8

SUMMARY OF SPENT FUEL TRANSPORTATION MECHANICAL ENVIRONMENT(7)

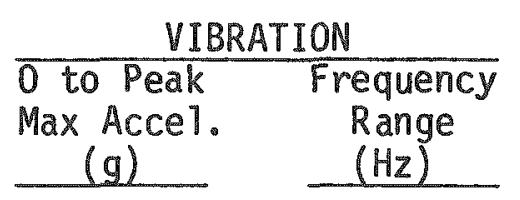

\begin{tabular}{cc}
\multicolumn{2}{c}{ SHOCK } \\
\hline Peak & Pulse \\
Accel. & Duration \\
(g) & (ms) \\
\hline
\end{tabular}

TRUCK

(Shock superimposed on vibration)

$\begin{array}{lll}\text { Longitudinal } & 1.50 & 0-1900 \\ \text { Transverse } & 1.17 & 0-1900 \\ \text { Vertical } & 2.00 & 0-1900\end{array}$

2.8

20

$\tilde{0}$

Vertica

\begin{abstract}
(2.00
\end{abstract}
$0-1900$

$\begin{array}{ll}2.3 & 19 \\ 7.0 & 77\end{array}$

\title{
RAIL
}

(Shock superimposed on vibration)

$\begin{array}{lllll}\text { Longitudinal } & 0.19 & 0-350 & 4.7 & 14 \\ \text { Transverse } & 0.19 & 0-350 & 4.7 & 14 \\ \text { Vertical } & 0.37 & 0-350 & 4.7 & 14\end{array}$

(Coupling $11 \mathrm{mph}$ )

$\begin{array}{lll}\text { Longitudinal } & - & - \\ \text { Vertical } & -- & -\end{array}$

39.0

$26.0 \quad 9$


TABLE 5.9

\section{RADIOACTIVITY CHANGE RATE}

\begin{tabular}{ll}
$\begin{array}{c}\text { Rate } \\
\text { CCAT-CCBT } \\
t\end{array}$ & Time \\
(uCi/ml-hr) & (hr) \\
\hline CASK COOLANT DUR ING & TRANSIT
\end{tabular}

Radioactivity
Change
No. of

Condition
of Fuel

CCAT-CCBT Radioactivity

Shipped Fuel

Cask Species

Assemblies

Assembly

Media

$\underline{\text { Clad }}$

Reactor

CASK COOLANT DUR ING TRANSIT

$\begin{array}{lrll}0.0088 & 48 & 0.42 & 137 \mathrm{Cs} \\ 0.0060 & 48 & 0.289 & \\ 0.0037 & 30 & 0.111 & 137 \mathrm{Cs} \\ 0.00003 & 288 & 0.009 & \text { Total } \\ 0.000063 & 30 & 0.0019 & 137 \mathrm{Cs} \\ 0.000018 & 48 & 0.00089 & 137 \mathrm{Cs} \\ 0.000006 & 48 & 0.00027 & 137 \mathrm{Cs}\end{array}$

$\begin{array}{rll}5 & \text { Leakers } & \text { Dry } \\ 2 & \text { Leakers } & \text { Wet } \\ 2 & \text { Leakers } & \text { Wet } \\ 1 & \text {... } & \text { Wet } \\ 24 & \text { Non-Leakers } & \text { Wet } \\ 5 & \text { Non-Leakers } & \text { Dry } \\ 2 & \text { Non-Leakers } & \text { Wet }\end{array}$

Design

\section{CASK COOLANT BEFORE TRANSIT}

w

$\begin{array}{lll}0.092 & 18-25 & .048-4.04 \\ 0.231 & \text { After } 2 & 0.462 \\ 0.026 & \text { After } 4 & 0.051 \\ 0.0065 & \text { After } 6 & 0.013 \\ -0.14 & \text { After } 8 & -0.028 \\ 0.0025 & \text { After 10 } & 0.005 \\ 0.038 & \text { After 12 } & 0.076 \\ 0.0 & \text { After 14 } & 0.0 \\ 0.010 & \text { After 16 } & 0.021 \\ -0.020 & \text { After 18 } & -0.04 \\ 0.0 & \text { After 20 } & 0.0 \\ 0.035 & \text { After 22 } & 0.035 \\ 0.005 & \text { After 24 } & 0.01\end{array}$

Total
$\mathrm{Cs}$
$\mathrm{Cs}$
$\mathrm{Cs}$
$\mathrm{CS}$
$\mathrm{CS}$
$\mathrm{CS}$
$\mathrm{CS}$
$\mathrm{CS}$
$\mathrm{CS}$
$\mathrm{CS}$
$\mathrm{CS}$

$\begin{array}{cl}9 & \ldots \\ 1 & \text { Leaker } \\ C-46 & \text { Leaker } \\ C-46 & \text { Leaker } \\ C-46 & \text { Leaker } \\ C-46 & \text { Leaker } \\ C-46 & \text { Leaker } \\ C-46 & \text { Leaker } \\ C-46 & \text { Leaker } \\ C-46 & \text { Leaker } \\ C-46 & \text { Leaker } \\ C-46 & \text { Leaker } \\ C-46 & \text { Leaker }\end{array}$

Wet
Wet
Wet
Wet
Wet
Wet
Wet
Wet
Wet
Wet
Wet
Wet
Wet

BWR

PWR

PWR

PWR

PWR

PWR

PWR

PWR

PWR

PWR

PWR

PWR

PWR 
Examination of one known leaker (San Onofre, C-46) over a series of two-hour intervals showed that most ( $87 \%$ ) of the change in radioactivity levels occurred during the first two hours. This suggests that after the first two hours, the changes in radioactivity level seem to be on the same order as the precision of the measurements. It is also possible to observe from Table 5.9 that after the first two hours of sampling, the rate of change becomes about a decade less.

No direct data on mechanical damage of spent fuel were found. However, examinations for such damage are not clearly distinguished from nontransportation-induced damage.

\subsection{Wet Versus Dry Shipments}

Very little data could be obtained on the radioactivity leveis of dry shipments.

Dry shipments are probably not completely dry, but filled with air that has some moisture level. Samples for radioactivity are taken from rinse solutions and the cask is later drained. This contributes uncertainties: Does any corrosion occur after rinsing? Is the time duration of the rinse solution comparable to pre- and post-samples from wet shipments? Transpor tation vibration occurring during transport of dry cask shipments could distribute a dry powder and/or gas contamination within the cask: this is contrasted with the distribution of solubles or suspended particles during wet cask shipments. The influence of thermal cycling on crud adherence and flaking was not addressed by this study. .

Examination of the data in Table 5.9 shows only two series of shipments that are comparable. These shipments are the San Onofre-to-Morris 1978 shipments of two wet and five dry nonleaking fuel assemblies. The comparison in Table 5.10 shows that the dry shipment has a 2.8 times greater radioactivity level than wet shipments after shipping and 0.2 for the change in radioactivity before and after shipping. However, the comparison is doubtful 
for several reasons: 1) The small population available for comparison could be dramatically affected by a single measurement error, 2) The levels were so low that they might have been influenced by the errors associated with sampling and measurement, and 3) the higher values for the dry shipment do not seem consistent considering the potential for fluid agitation during wet shipments.

TABLE 5.10

COMPARISON OF WET VERSUS DRY SHIPMENTS

San Onofre Non-Leaking SS Clad (Total CS)

$\begin{array}{lll}\text { After Transport } & \text { Max Radioactivity } & \text { No. of Fuel } \\ \operatorname{Max}(\mu \mathrm{Ci} / \mathrm{m} \mathrm{l}) & \text { Changes* }(\mu \mathrm{Ci} / \mathrm{m} \mathrm{l}) & \text { Assemblies }\end{array}$

Wet

0.00075

0.00027

2

Dry**

0.0021

0.00137

5

$$
\frac{0.0021}{0.00075}=2.8
$$

$\frac{0.00027}{0.00137}=0.2$

\footnotetext{
* Radioactivity change, before-transit measurement less after-transit measurement

** Rinse samples
}

For these several reasons, it seems better to conclude that the differences between wet and dry shipments are too complex to compare at this stage of data development.

\subsection{Radioactivity Level Predictions}

A possible basis for identifying degradation of spent fuel during transportation is provided by comparing the projected increase in radioactivity 
levels in cask coolant to the actual radioactivity level found after transportation. The projection is developed by extrapolating two measurements of cask coolant before transportation to post transportation time. An increase of the actual measurements to above the extrapolated value would suggest an additional new source of radioactivity during transit. Although it is probable that the new source of radioactivity is leaking from the fuel rod interior, other sources are possible, such as agitation of contamination in the cask prior to loading. This source could depend on the motion of the cask during transportation to stir contamination up from the walls or less accessible locations of the cask. A projection less than that of the extrapolation at least suggests that no new radioactivity is being added to the system. However, this assumption also needs to compensate for a decrease with time of the leaking through cladding, which was found in the carefully logged San Onofre C-46 assembly.

Two separate truck shipments from Haddam Neck show (Figure 5.1) very large increases in radioactivity level over the available extrapolated values. These shipments were each for a single PWR assembly during the 1973 discharge date for fuel; historical data for that year shows a peak number of indicated leaking spent fuel assemblies.

In contrast, the one rail shipment from Big Rock Point showed much lower actual radioactivity after transport than the extrapolation. This shipment contained 10 separate BWR assemblies, some of which were known leakers. One San Onofre spent fuel assembly, PWR C-46, which had been identified as a known leaker, showed very much lower radioactivity level than predicted by extrapolation.

It is not possible from these conflicting results to ascertain whether degradation of LWR fuel during transportation is actualiy happening. Additional cases must be added to the data base, and compensation for existing cask contamination needs to be applied to the analysis. 


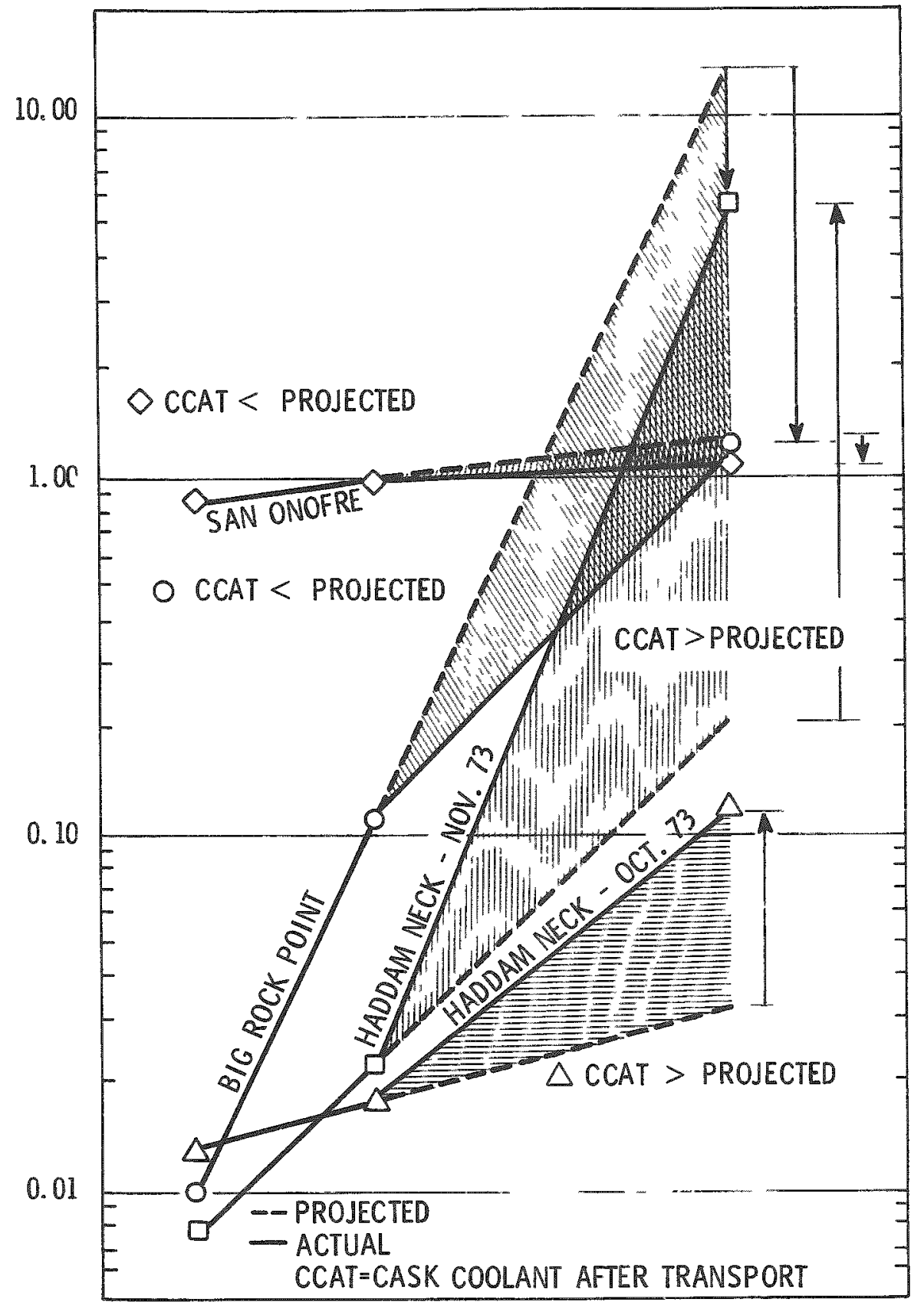

HEDL 7808-136.1

FIGURE 5.1. Comparison of Radioactivity Forecast with Actual AfterTransport Measurements. Neg 7809501-1 


\subsection{REFERENCES}

1. Code of Federal Regulations, 10CFR, Section 71.35, P. 383, 1977.

2. Table: "Physical Constants of Inorganic Compounds," in Handbook of Chemistry and Physics, The Chemical Rubber Publishing Co., Cleveland, $\mathrm{OH}, \mathrm{pp} .560-561$.

3. E. A. Guinn, Design and Operational Characteristics of High-Density Fuel Storage Facilities, NEDO-21837, General Electric, San Jose, CA, February 24, 1978.

\section{BIBLIOGRAPHY}

1. S. R. Fields, SAVIT - A Dynamic Model to Predict Vibratory Motion Within a Spent Fuel Shipping Cask - Rail Car System, HEDL-TME 77-45, Hanford Engineering Development Laboratory, Richland, WA, March 1978.

2. S. R. Fields, STORE - A Systems Dynamics Model of Spent Fuel Storage and Logistics in the LWR Fuel Cycle, HEDL-TME 77-50, Hanford Engineering Development Laboratory, Richland, WA, March 1978.

3. J. F. Strahel and E. N. Cramer, Relative Time Integrated Spent Fuel Storage Hazard, Southern California Edison Co., NAS Corp., June 20,1978 .

4. C. F. Magnuson and L. T. Wilson, Shock and Vibration Environments for Large Shipping Containers on Rail Cars and Trucks, SAND-76-0427, Sandia Laboratories, ATbuquerque, NM, July 1977.

5. W. V. Loscutoff, E. S. Murphy, L. L. Clark, R.W. Mckee, R. J. Hall and R. E. Rhoads, A Safety and Economic Study of Special Trains for Shipment of Spent Fuel, BNWL-2263, Pacific Northwest Laboratory, Richland, WA, December 1977.

6. C. J. Edney, et a1., Some U.K. Experience and Practice in the Packaging and Transport of Irradiated Fuel, IAEA-CN-36/70, International Atomic Energy Agency, Vienna, Austria, 1977.

7. H.W. Curtis, Experience of European Irradiated Fuel Transport - The First Four Hundred Tonnes, IAEA-CN-36/69, International Atomic Energy Agency, Vienna, Austria, 1977.

8. Shipments of Nuclear Fuel and Waste...Are They Really Safe?, DOE-EV/004, U.S. Department of Energy, Transport Branch, Washington, DC, 1977.

9. Hazardous Materials Transportation, Part 2: Radioactive Materials and Wastes, NTIS/PS 77/0406, NTI Search, 1977. 


\section{BIBLIOGRAPHY (Cont' $d$ )}

10. A. M. Platts, Nuclear Waste Management and Transportation, Quarterly Prooress Report JuTy Through September, BNWL-2179, Pacific Northwest Laboratory, Richland, WA, 1977.

11. A. M. Platt, et a1. United States Experience in the Transportation of Radioactive Materials, IAEA-CN-36/563, International Atomic Energy Agency, Vienna, Austria, 1977.

12. W. V. Loscutoff and R. J. Hal1, Safety and Economic Study of Special Trains, BNWL-SA-5770, Pacific Northwest Laboratory, Richland, WA, 1976.

13. Proceedings of the International Symposium on the Management of Wastes from the LWR Fuel Cycle, CONF-760701, Denver, CO, July 11-16, 1976.

14. "Transportation Alternatives," in Alternatives for Managing Wastes from Reactors and Post-Fission Operations in the LWR Fuel CycTe, ERDA-76-43, VoT. 3, Ch. 22, U.S. Department of Energy, Washington, DC, May 1976.

15. Specialists Meeting on the Behavior of Water Reactor Fuel Elements Under Accident Conditions, INIS-MF-3224, Spaatind, Norway, September 13-16, 1976.

16. D. R. Smith, R. E. Luna, J. M. Taylor and A. R. DuCharme, Risk Assessment for the Transportation of Radioactive Materials in the USA, SAND-76-5373, Sandia Laboratories, ATbuquerque, NM, 1976.

17. H. R. Yoshimura and M. Huerta, Full-Scale Tests of Spent-Nuclear-Fuel Shipping Systems, SAND-76-5707, Sandia Laboratories, Albuquerque, NM, 1976.

18. J. 0. Blomeke, Impact of Nuclear Fuel Cycle Centers on Shipping Special Nuclear MateriaTs and Wastes, CONF-750846-1, U.S. Department of Energy, Washington, DC, 1975.

19. Technical Description: IF300 Irradiated Fuel Shipping Cask, General Electric, San Jose, CA, 1975.

20. U.S. Nuclear Regulatory Commision Standard Review Plan, Spent Fuel Storage, NUREG-75/087, US Nuclear Regulatory Commission, Washington, DC, 1975.

21. L. B. Shappert, W. E. Unger and J. M. Freedman, Spent and Fresh Fuel Shipping Cask Considerations, SAND-75-5658, Sandia Laboratories, Albuquerque, NM, 1975.

22. Humbolt Bay Power Plant $\# 3$, Technical Specifications. Amendment \#9, Docket-50133-263, Pacific Gas and ETectric Company, San Francisco, CA, JuTy 1975. 


\section{BIBLIOGRAPHY (Cont'd)}

23. H. B. Robinson Plant \#2, Request for Waiver for Spent Fuel Shipment, Docket-50261-507, Carolina Power and Light Company, Raleigh, NC, June 1975.

24. Monticello Nuclear Generating Plant \#1, Status Report on Plant for off-Site Shipment of Spent Fuel, Docket-50263-490, Northern States Power Company, Minneapolis, MN, June 1975.

25. L. F. Morrow and C. E. Nichols, Receipt of Irradiated Fuel Shipments at the ICPP-NRTS, CONF-740901-P.2, U.S. Department of Energy, Washington, DC, pp. 1020-1026, 1974.

26. W. A. Pryor, Irradiated Fuel and Control Rods Transport from a Decommissioned Power Reactor, CONF-741018, U.S. Department of Energy, Washington, DC, PP. 375-382, 1974.

27. K. H. Dufrane, Design, Manufacturing and Operational Experience with the NFS-4 Spent Fuel Shipping Cask, CONF-740901-P.1, U.S. Department of Energy, Washington, DC, pp. 138-149, 1974.

28. M. J. Szulinski, Hanford Decontamination Facility, ARH-SA-181, Atlantic Richfield Hanford Company, Richland, WA, March 1974.

29. Guidance on the License Application, Siting, Design and Plant Protection for an Independent Spent Fuel Storage Installation, U.S. Atomic Energy Commission, 1974.

30. Point Beach Nuclear Plant, Notification of Intent to Transfer Spent Nuclear Fuel, Docket-50266-187, Wisconsin Electric Power Company, Milwaukee, WI, JuTy 1974.

31. J. A. Richardson, "Radioactive Waste Quantities Produced by LWR and Methods of Storage, Transport and Disposal," J. Brit. Nucl. Eng. Soc. 12.

32. Dresden Nuclear Power Station 42 , Analyses and Procedures for Handling G.E. IF-300 Spent Fuel Shipping Cask, Report "28, Docket-50237-333, Commonwealth Edison Company, Chicago, IL, June $197 \overline{3}$.

33. Transportation of Nuclear Spent Fuel Administrator's Guide No. 3. NP-19065, Southern Interstate Nuclear Board, At7anta, GA, 111 pp., 1972.

34. K. H. Dufrane, "Past Experience and Future Trends in the Transportation of Spent Nuclear Fuel, "in Proceedings of the American Power Conference. 34, pp. 188-194, 1972.

35. Aguirre Nuclear Plant A1, Preliminary Facility Description and Safety Analysis Report, Vol. 3, Docket $-57376-5$, Puerto Rico Water Resources Authority, San Juan, PR, December 1970. 
APPENDIX

SUMMARY OF SHIPPING DATA ASSEMBLED BY HEDL

$A-1$ 


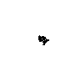


TABLE $A-1$

COMMERCIAL LWR FUEL SHIPPED TO MORRIS

\begin{tabular}{|c|c|c|c|c|c|}
\hline Plant & Utility & MTHM & $\begin{array}{l}\text { No. of Fuel } \\
\text { Assemblies }\end{array}$ & $\begin{array}{l}\text { No. of } \\
\text { Shipments }\end{array}$ & Shipping Mode \\
\hline Dresden & Commonwealth Edison, IL & 144.7 & 753 & 43 & RR IF300 \\
\hline San Onofre & Southern California Edison, CA & 53.3 & 150 & 150 & Truck \\
\hline Haddam Neck & Connecticut Yankee Atomic Power, CT & 32.9 & 80 & 80 & Truck \\
\hline Point Beach & Wisconsin Electric Power Co., WI & 27.8 & 72 & 72 & Truck \\
\hline
\end{tabular}

TABLE A-2

COMMERCIAL LWR FUEL SHIPPED TO WEST VALLEY(3)

$\begin{array}{llccc} & & \text { kg/MTHM } & \begin{array}{c}\text { No. of Fuel } \\ \text { Assemblies }\end{array} & \begin{array}{c}\text { No. of } \\ \text { Shipments }\end{array} \\ \text { Yankee Rowe } & \text { Yankee Atomic Electric, MA } & 420,435 & 206 & 175 \\ \text { Indian Pt-1 } & \text { Consolidated Edison, NY } & & & 265 \\ \text { Humbolt Bay } & \text { Pacific Gas \& Electric, CA } & & 65 \\ \text { Big Rock Pt. } & \text { Consumers Power Company, MI } & 11,130 & 85 & 75 \\ \text { Haddam Neck } & \text { Connecticut Yankee Atomic Power, CT } & & 575 \\ \text { San Onofre-1 } & \text { Southern California Edison, CA } & & & 430 \\ \text { Oyster Creek } & \text { Jersey Central Power \& Light, NJ } & 42,756 & 224 & 640 \\ \text { Nine Mile Pt. } & \text { Niagara Mohawk Power, NY } & & & 625\end{array}$


TABLE A-3

\section{POINT BEACH SHIPMENT DATA}

From: Two Rivers, WI

Fuel: PUR, $\mathrm{Zr}-\mathrm{Clad}$
To: General Electric Morris Operations

R.R. 1

Morpis, IL.

Shipping Conditions: Wet, Demineralized Water, 220 Miles, 1 day/truck

\begin{tabular}{|c|c|c|c|c|c|c|}
\hline \multirow{2}{*}{$\begin{array}{l}\text { Shipment } \\
\text { Mumber }\end{array}$} & \multicolumn{2}{|c|}{ Date } & \multirow{2}{*}{$\begin{array}{l}\text { Fuel Assembiy } \\
\text { Number }\end{array}$} & \multicolumn{3}{|c|}{$137 \mathrm{Cs} \mu \mathrm{Ci} / \mathrm{ml}$ of Cask Coolant } \\
\hline & Shipped & Received & & Before Transport & After Transport & Change \\
\hline 1 & $7 / 7$ & $7 / 8$ & A40 & .00062 & .00051 & -.00011 \\
\hline 2 & $7 / 12$ & $7 / 13$ & 041 & .00054 & .0028 & .00226 \\
\hline 3 & $7 / 15$ & $7 / 16$ & A02 & .00034 & .0039 & .00356 \\
\hline 4 & $7 / 16$ & $7 / 17$ & A18 & .00066 & .0014 & .00074 \\
\hline 5 & $7 / 17$ & $7 / 18$ & C51 & .00072 & .0038 & .00308 \\
\hline 6 & $7 / 19$ & $7 / 19$ & B52 & .00019 & .0008 & .00061 \\
\hline 7 & $7 / 20$ & $7 / 20$ & B79 & .00036 & .0038 & .00344 \\
\hline 8 & $7 / 21$ & $7 / 21$ & $B 90$ & NA & .0021 & $-\infty$ \\
\hline 9 & $7 / 22$ & $7 / 22$ & 858 & .00039 & .0024 & .00201 \\
\hline 10 & $7 / 23$ & $7 / 23$ & B77 & NA & .0009 & - \\
\hline 11 & $7 / 24$ & $7 / 26$ & $B 53$ & .00034 & .091 & .09066 \\
\hline 12 & $7 / 27$ & $7 / 28$ & $B 71$ & .00031 & NA & -- \\
\hline 13 & $7 / 28$ & $7 / 28$ & B64 & .00045 & .0061 & .00565 \\
\hline 14 & $7 / 31$ & $8 / 01$ & 867 & .00014 & .0018 & .00166 \\
\hline 15 & $8 / 02$ & $8 / 03$ & 888 & NA & .003 & -- \\
\hline 16 & $8 / 05$ & $8 / 06$ & $B 69$ & NA & .0012 & - \\
\hline 17 & $8 / 06$ & $8 / 07$ & 889 & NA & .0045 & -- \\
\hline 18 & $8 / 08$ & $8 / 08$ & 884 & .00034 & .00158 & .00124 \\
\hline 19 & $8 / 10$ & $8 / 11$ & $B 68$ & NA & .0016 & -- \\
\hline 20 & $8 / 27$ & $8 / 29$ & $B 63$ & .00009 & .00136 & .00127 \\
\hline 21 & $8 / 30$ & $8 / 30$ & $B 56$ & .00041 & .00051 & .0001 \\
\hline 22 & $8 / 31$ & $9 / 01$ & B59 & .0002 & .0046 & .0044 \\
\hline 23 & $9 / 01$ & $9 / 01$ & B65 & .00002 & NA & $-\infty$ \\
\hline 24 & $9 / 02$ & $9 / 03$ & 876 & .0008 & .00205 & .00125 \\
\hline 25 & $9 / 03$ & $9 / 03$ & $B 85$ & .00007 & MA & $-\infty$ \\
\hline 26 & $9 / 04$ & $9 / 07$ & B57 & .00006 & .00121 & .00115 \\
\hline 27 & $9 / 07$ & $9 / 08$ & $B 73$ & .0006 & .00029 & -.00031 \\
\hline 28 & $9 / 08$ & 9/09 & $B 62$ & NA & .0012 & $-\cdots$ \\
\hline 29 & $9 / 09$ & $9 / 10$ & B66 & .00079 & .130 & .1292 \\
\hline 30 & $9 / 11$ & $9 / 11$ & B54 & .00009 & .0022 & .00211 \\
\hline 31 & $9 / 13$ & $9 / 14$ & B61 & .00007 & .0066 & .00653 \\
\hline 32 & $9 / 15$ & $9 / 15$ & $B 80$ & .000098 & .00165 & .001552 \\
\hline 33 & $9 / 15$ & $9 / 16$ & B87 & .000042 & .00157 & .001528 \\
\hline 34 & $9 / 17$ & $9 / 17$ & B72 & .00024 & .0016 & .00136 \\
\hline 35 & $9 / 18$ & $9 / 18$ & B83 & .00058 & .0007 & .00012 \\
\hline 36 & $9 / 20$ & $9 / 21$ & $B 78$ & .00018 & .0015 & .00132 \\
\hline 37 & $9 / 21$ & $9 / 22$ & 886 & .00004 & .00007 & .00003 \\
\hline 38 & $9 / 23$ & $9 / 23$ & $B 60$ & .00004 & .00065 & .00061 \\
\hline
\end{tabular}


TABLE $A-4$

\section{POINT BEACH SHIPMENT DATA}

From: Two Rivers, WI

Fue 1: PHR, 2R-Clad
To: General Electric Morpis Operations R.R. 1

Morris, Il

Shipping Conditions: Wet, Demineralized Water, 220 Miles, .1 day/truck

\begin{tabular}{|c|c|c|c|c|c|c|c|}
\hline \multirow{2}{*}{$\begin{array}{l}\text { Fue l Assemb ly } \\
\text { Number } \\
\end{array}$} & \multirow{2}{*}{\multicolumn{3}{|c|}{ Date }} & \multirow{2}{*}{$\begin{array}{l}\text { Burnup } \\
\text { Mud/T }\end{array}$} & \multicolumn{3}{|c|}{$\begin{array}{l}\text { Total Activity of Cask Coolant (uCi/mi) } \\
\text { Before Transport After Transport } \\
\text { Change }\end{array}$} \\
\hline & & & & & Before Transport & After Transport & Change \\
\hline B51 & $11 / 21 / 74$ & $6 / 01 / 77$ & $6 / 01 / 77$ & 29,665 & .00646 & .076 & .070 \\
\hline 033 & 福 & $6 / 03 / 77$ & $6 / 04 / 77$ & 34.458 & .00293 & .064 & .061 \\
\hline A90 & $11 / 23 / 74$ & $6 / 05 / 77$ & $6 / 06 / 77$ & 25,864 & .00472 & .088 & .083 \\
\hline A85 & $11 / 19 / 74$ & $6 / 07 / 77$ & $6 / 07 / 77$ & 26,185 & .00482 & .26 & .255 \\
\hline B81 & $11 / 22 / 74$ & $6 / 09 / 77$ & $6 / 09 / 77$ & 29,527 & .000159 & .067 & .0668 \\
\hline 875 & $11 / 22 / 74$ & $6 / 11 / 77$ & $6 / 11 / 77$ & 29,671 & $M A$ & .17 & -- \\
\hline B82 & $11 / 22 / 74$ & $6 / 13 / 77$ & $6 / 13 / 77$ & 29,949 & .00433 & .072 & .068 \\
\hline A67 & $11 / 22 / 74$ & $6 / 15 / 77$ & $6 / 15 / 77$ & 26,079 & .0125 & .16 & .148 \\
\hline A88 & $11 / 25 / 74$ & $6 / 17 / 77$ & $6 / 17 / 77$ & 28,002 & .0000448 & .20 & .1996 \\
\hline A59 & $11 / 21 / 74$ & $6 / 20 / 77$ & $6 / 20 / 77$ & 25,656 & .0146 & .076 & .061 \\
\hline$A 61$ & $11 / 22 / 74$ & $6 / 22 / 77$ & $6 / 22 / 77$ & 25,853 & .00434 & .012 & .082 \\
\hline A84 & $11 / 25 / 74$ & $6 / 24 / 77$ & $6 / 24 / 77$ & 28,065 & .0421 & .18 & .176 \\
\hline D26 & $12 / 11 / 75$ & $6 / 27 / 77$ & $6 / 27 / 77$ & 26,911 & .00781 & .090 & .082 \\
\hline 018 & $12 / 15 / 75$ & $6 / 29 / 77$ & $6 / 30 / 77$ & 23,102 & .0116 & .053 & .041 \\
\hline D3i & $12 / 13 / 75$ & $7 / 01 / 77$ & $7 / 02 / 77$ & 23,426 & .00399 & .015 & .011 \\
\hline$C 52$ & $3 / 16 / 77$ & $7 / 06 / 77$ & $7 / 06 / 77$ & 32,818 & .00470 & .25 & .245 \\
\hline 654 & $3 / 15 / 77$ & $7 / 07 / 77$ & $7 / 07 / 77$ & 36,017 & .0180 & .39 & .372 \\
\hline$C 55$ & $3 / 16 / 77$ & $7 / 08 / 77$ & $7 / 08 / 77$ & 39,949 & .0140 & .36 & .346 \\
\hline C56 & $3 / 16 / 77$ & $7 / 11 / 77$ & $7 / 12 / 77$ & 40,071 & .0386 & .17 & .135 \\
\hline 557 & $3 / 15 / 77$ & $7 / 12 / 77$ & $7 / 12 / 77$ & 38,269 & .0195 & .19 & .171 \\
\hline C58 & $3 / 16 / 77$ & $7 / 13 / 77$ & $7 / 13 / 77$ & 40,307 & .0164 & .093 & .077 \\
\hline 659 & $3 / 16 / 77$ & $7 / 14 / 77$ & $7 / 14 / 77$ & 33,062 & .0258 & .47 & .444 \\
\hline C63 & $3 / 16 / 77$ & $7 / 15 / 77$ & $7 / 15 / 77$ & 40,422 & .0232 & .40 & .377 \\
\hline C64 & $3 / 16 / 77$ & $7 / 18 / 77$ & $7 / 18 / 77$ & 40,554 & .0413 & .32 & .279 \\
\hline$c 65$ & $3 / 16 / 77$ & $7 / 19 / 77$ & $7 / 19 / 77$ & 36,013 & .0675 & .29 & .223 \\
\hline$c 66$ & $3 / 16 / 7 ?$ & $7 / 21 / 77$ & $7 / 21 / 77$ & 36,412 & .0313 & .49 & .460 \\
\hline 667 & $3 / 16 / 77$ & $7 / 21 / 77$ & $7 / 21 / 77$ & 40,102 & .0249 & .11 & .085 \\
\hline C68 & $3 / 15 / 77$ & $7 / 25 / 77$ & $7 / 25 / 77$ & 38,113 & .0220 & .12 & .098 \\
\hline 670 & $3 / 17 / 77$ & $7 / 26 / 77$ & $7 / 26 / 77$ & 33,079 & .0284 & .071 & .043 \\
\hline$C 72$ & $3 / 16 / 77$ & $7 / 27 / 77$ & $7 / 27 / 77$ & 37,854 & .0330 & .076 & .043 \\
\hline$C 73$ & $3 / 17 / 77$ & $7 / 28 / 77$ & $7 / 28 / 77$ & 33,539 & .0330 & .29 & .257 \\
\hline 674 & $3 / 16 / 77$ & $7 / 29 / 77$ & $7 / 29 / 77$ & 36,065 & .0249 & .30 & .275 \\
\hline 675 & $3 / 15 / 77$ & $8 / 01 / 77$ & $8 / 01 / 77$ & 35,943 & .0342 & .14 & .106 \\
\hline 676 & $3 / 15 / 77$ & $8 / 02 / 77$ & $8 / 02 / 77$ & 40,456 & .0454 & .081 & .036 \\
\hline$c 77$ & $3 / 16 / 77$ & $8 / 03 / 77$ & $8 / 03 / 77$ & 36,105 & .050 & .14 & .09 \\
\hline $\mathrm{C} 78$ & $3 / 16 / 77$ & $8 / 04 / 77$ & $8 / 04 / 77$ & 33,419 & .128 & .39 & .262 \\
\hline
\end{tabular}


TABLE A-5

SELECTED SAN ONOFRE SHIPMENT DATA

From: San Clemente, CA

To: General Electric Morris Operations R.R. 1

Fuel: PWR, SS Clad Morris, IL

Shipping Condition: Wet and ory, 1900 Miles, 2-4 days/truck

Fuel Assembly Number

$\begin{array}{ll}036 & 7 / 14 / 77 \\ 039 & 7 / 25 / 77 \\ 042 & 7 / 27 / 77 \\ E 19 & 10 / 26 / 77 \\ E 22 & 11 / 22 / 77 \\ E 32 & 11 / 25 / 77 \\ \text { E40 } & 12 / 19 / 77 \\ \text { C46-1 } & 2 / 22 / 78 \\ \text { C46-2 } & 2 / 22 / 78 \\ \text { C46-3 } & 2 / 22 / 78 \\ \text { C46-4 } & 2 / 22 / 78 \\ \text { C46-5 } & 2 / 22 / 78 \\ \text { C46-6 } & 2 / 22 / 78 \\ \text { C46-7 } & 2 / 22 / 78 \\ C 46-8 & 2 / 22 / 78 \\ \text { C46-9 } & 2 / 22 / 78 \\ \text { C46-10 } & 2 / 22 / 78 \\ \text { C46-11 } & 2 / 22 / 78 \\ \text { C46-12 } & 2 / 22 / 78 \\ \text { C46-13 } & 2 / 22 / 78 \\ \text { C21 } & 3 / 01 / 78 \\ \text { C28 } & 3 / 02 / 78 \\ \text { C47 } & 3 / 03 / 78\end{array}$

$137 \mathrm{Cs} \mathrm{uCi/ml}$ of Cask Coolant

\begin{tabular}{|c|c|c|}
\hline Before Transport & After Transport & Change \\
\hline .00073 & .0021 & .00139 \\
\hline .00147 & .00013 & -.00134 \\
\hline .000115 & .00012 & .00011 \\
\hline$-\infty$ & .00075 & - \\
\hline .000073 & .00037 & .000297 \\
\hline- & .00033 & - \\
\hline- & .00005 & - \\
\hline .498 & & \\
\hline .861 & & \\
\hline .890 & & \\
\hline .899 & & \\
\hline .877 & . & \\
\hline .883 & & \\
\hline .959 & & \\
\hline .957 & & \\
\hline .978 & & \\
\hline .908 & & \\
\hline .913 & & \\
\hline .980 & & \\
\hline .989 & 1.10 & .111 \\
\hline .03054 & .24 & .21 \\
\hline .11853 & .15 & .031 \\
\hline .00650 & .19 & .184 \\
\hline
\end{tabular}

NA $=$ Not applicable. 
TABLE $A-6$

SELECTED HADDAM NECK SHIPMENT DATA

From: Haddam, CT

Fuel: PWR, $\mathrm{Zr}-\mathrm{Cl}$ ad

Shipping Conditions: Wet, Deionized Water, 900 Miles, v2-3 days/truck
To: General Electric Morris Operations R.R. 1

Morris, IL

\begin{tabular}{|c|c|c|c|c|c|c|c|c|}
\hline \multirow[b]{2}{*}{$\begin{array}{l}\text { Shipment } \\
\text { Number }\end{array}$} & \multirow[b]{2}{*}{$\begin{array}{c}\text { Cask } \\
\text { Number }\end{array}$} & \multirow[b]{2}{*}{$\begin{array}{c}\text { Measurement } \\
\text { Date } \\
\end{array}$} & \multirow[b]{2}{*}{$\begin{array}{l}\text { Burnup } \\
\text { MWd/MTU }\end{array}$} & \multicolumn{5}{|c|}{ Gross Activity, $\mathrm{ci} / \mathrm{ml}$} \\
\hline & & & & $\begin{array}{l}\text { Before } \\
\text { First }\end{array}$ & $\begin{array}{l}\text { Transport } \\
\text { Second }\end{array}$ & Change & $\begin{array}{c}\text { After } \\
\text { Transport }\end{array}$ & $\begin{array}{c}\text { After Minus } \\
\text { Before (Second) }\end{array}$ \\
\hline $66-2-15$ & 002 & $8 / 13 / 73$ & 27,302 & .00011 & .00012 & .00001 & NA & $-\infty$ \\
\hline $67-2-16$ & 003 & $8 / 13 / 73$ & 27,302 & .000035 & .0027 & .002665 & NA & $-\infty$ \\
\hline $68-2-16$ & 001 & $9 / 07 / 73$ & 27,302 & .000029 & .00044 & .000411 & NA & -- \\
\hline $69-2-18$ & 002 & $10 / 12 / 73$ & 27,302 & .000091 & .013 & .0129 & NA & -- \\
\hline $70-2-19$ & 003 & $10 / 16 / 73$ & 26,241 & .0022 & .031 & .0288 & NA & -- \\
\hline $71-2-20$ & 001 & $10 / 29 / 73$ & 26,241 & .0076 & .023 & .0154 & .580 & .567 \\
\hline $73-2-22$ & 003 & $11 / 09 / 73$ & 26,335 & .013 & .018 & .005 & .120 & .102 \\
\hline $73-2-23$ & 001 & $11 / 20 / 73$ & 26,403 & .00023 & .010 & .00977 & NA & -- \\
\hline $75-2-24$ & 002 & $5 / 15 / 74$ & 26,460 & .000024 & .0040 & .003976 & NA & -- \\
\hline $76-2-25$ & 003 & $5 / 21 / 74$ & 26,460 & .0016 & .00094 & -.00066 & NA & - \\
\hline $77-2-26$ & 001 & $5 / 31 / 74$ & 26,460 & .00034 & .00055 & .00021 & NA & $-\infty$ \\
\hline $78-2-26$ & 002 & $8 / 08 / 74$ & 26,466 & .00013 & .0043 & .00417 & NA & -- \\
\hline $79-2-28$ & 003 & $8 / 02 / 74$ & 26,466 & .042 & .042 & .0 & NA & -- \\
\hline $80-2-29$ & 001 & $7 / 02 / 74$ & 26,495 & .00034 & .0059 & .00556 & NA & -- \\
\hline
\end{tabular}

NA - Not Available; Measurements were not made. 
TABLE $A-7$

SELECTED BIG ROCK POINT SHIPMENT DATA

From: Char levoix, MI

To: Nuclear Fuel Service

Fuel: $9 \times 9,11 \times 11$, BWR, $\mathrm{Zr}-\mathrm{Cl}$ ad West Valley, NY

Shipping Conditions: Wet, Demineralized Water, 2750 Miles, Rail

\begin{tabular}{|c|c|}
\hline $\begin{array}{l}\text { Shipment } \\
\text { Number }\end{array}$ & $\begin{array}{l}\text { Assemblies } \\
\text { Per Cask }\end{array}$ \\
\hline 18 & 10 \\
\hline 19 & 10 \\
\hline 20 & 10 \\
\hline 21 & 9 \\
\hline 22 & 8 \\
\hline 23 & 9 \\
\hline 24 & 6 \\
\hline 25 & 9 \\
\hline 27 & 7 \\
\hline
\end{tabular}

\begin{tabular}{c}
$\begin{array}{c}\text { Confirmed } \\
\text { Leakers }\end{array}$ \\
\hline 4 \\
5 \\
4 \\
4 \\
7 \\
4 \\
5 \\
4 \\
4
\end{tabular}

\begin{tabular}{|c|c|c|c|c|c|}
\hline \multicolumn{6}{|c|}{$\operatorname{Gross} B(\mu \mathrm{Ci} / \mathrm{ml})$} \\
\hline \multicolumn{3}{|c|}{ Before Transport } & & After & Transport \\
\hline First & Second & Change & I/hr & Transport & Time (days) \\
\hline .88 & .293 & -.587 & 21.5 & 1.2 & 6 \\
\hline .456 & .450 & -.006 & 20.0 & 1.35 & 10 \\
\hline .113 & .112 & -.001 & 20.5 & 0.79 & NA \\
\hline .0103 & 1.119 & 1.1087 & 23.5 & 1.2 & NA \\
\hline .224 & .0915 & -.1325 & 16.0 & .1 & 6 \\
\hline .281 & .76 & .479 & 24.5 & NA & NA \\
\hline .484 & 3.37 & 2.886 & 23.0 & NA & NA \\
\hline .0502 & .222 & .1718 & 18.0 & NA & NA \\
\hline .0321 & 1.323 & 1.2909 & 25 days 10 & NA & NA \\
\hline
\end{tabular}

NA - Not Available 


\section{DISTRIBUTION}

$\underline{U C-85}(107)$

DOE/RRT-HQ (2)

MaiT Stop B-107

Washington, DC 20545

Program Division Director

DOE/RL (2)

Program Manager. Alternate Fuel Cycle Development and Nuclear Materials Management

DOE/FFTFPO (5)

Director

Connecticut Yankee Atomic Power, Inc.

P.0. Box 127E

Haddam Neck

East Hampton, CT 06424

RH Groves, Superintendent

Sandia Laboratories

Division 4413

Albuquerque, NM 87185

N. Finley

Nuclear Fuel Service, Inc.

P. 0. Box 124

West Valley, NY 14171

JP Duckworth

Wisconsin Electric Power Company

231 West Michigan

Milwaukee, WI 53201

HS Shimon

General Electric Company

Morris Operation

7555 East Collins Road

Morris, IL 60450

EE Voiland 


\section{DISTRIBUTION (Cont'd)}

Southern California Edison

P.0. Box 800

2244 Walnut Grove Avenue

Rosemead, CA 91770

JW Handshuh

Big Rock Point Nuclear Plant

Box 591, Route 3

Charlevoix, MI 49720

LF Monshor

HEDL (33)

$\begin{array}{ll}\text { JM Atwood } & \text { W/C-45 } \\ \text { LD Blackburn } & \text { W/A-40 } \\ \text { AG Blasewitz } & \text { W/C-31 } \\ \text { MCJ Carlson } & \text { W/JAD-7 } \\ \text { JM Dahlke } & \text { W/C-115 } \\ \text { EA Evans } & \text { W/JAD-6 } \\ \text { SR Fields } & \text { W/FED-420 } \\ \text { JF Fletcher } & \text { W/FED-420 } \\ \text { CW Funk (2) } & \text { W/C-53 } \\ \text { EM Greene } & \text { W/FED-420 } \\ \text { LD Jacobson (2) } & \text { W/JAD-7 }\end{array}$

RL Knecht

JJ McCown

WE Roake

BA Shane

WF Sheely

JC Sonnichsen, Jr.

GL Steele

Central Files

Publ Services

Contract Admin

SW Berglin

$W / A-40$

W/C -53

$W / E-2$

W/FED-420

W/C-44

W/FED-420

W/JAD-7

(10) $W / C-110$
(2) $W / C-115$

W/A-21 